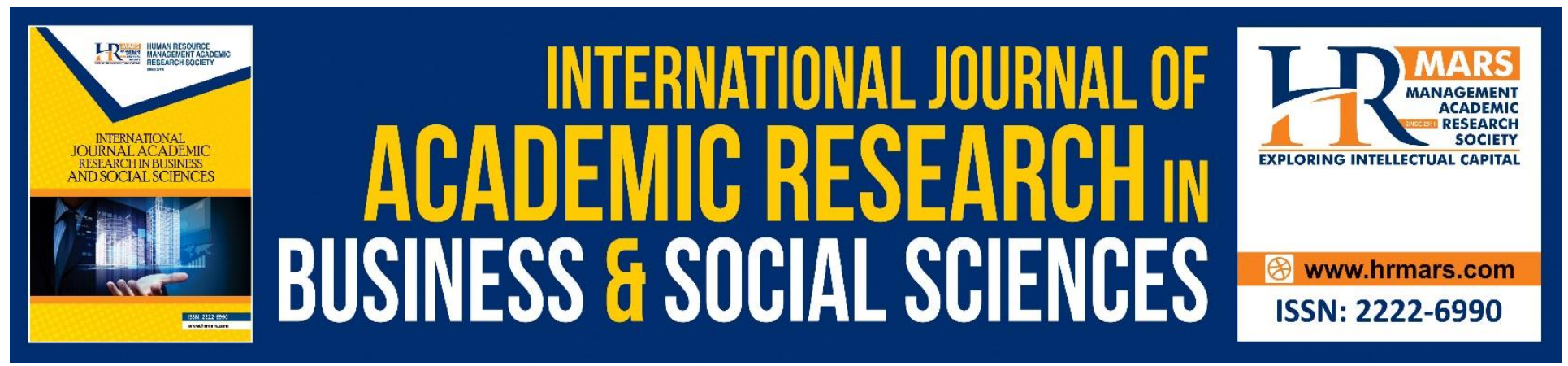

\title{
Interactions among Factors Affecting Micro Entrepreneur Performance in Sarawak, Malaysia
}

\section{Habsah Mohamad Sabli \& Hamrila Abdul Latiff}

To Link this Article: http://dx.doi.org/10.6007/IJARBSS/v9-i3/5650

DOI: $\quad 10.6007 /$ IJARBSS/v9-i3/5650

Received: 24 Feb 2019, Revised: 17 March 2019, Accepted: 30 March 2019

Published Online: 03 April 2019

In-Text Citation: (Sabli \& Latiff, 2019)

To Cite this Article: Sabli, H. M., \& Latiff, H. A. (2019). Interactions among Factors Affecting Micro Entrepreneur Performance in Sarawak, Malaysia. International Journal of Academic Research in Business and Social Sciences, 9(3), 208-218.

Copyright: (c) 2019 The Author(s)

Published by Human Resource Management Academic Research Society (www.hrmars.com)

This article is published under the Creative Commons Attribution (CC BY 4.0) license. Anyone may reproduce, distribute, translate and create derivative works of this article (for both commercial and non-commercial purposes), subject to full attribution to the original publication and authors. The full terms of this license may be seen

at: $\underline{\text { http://creativecommons.org/licences/by/4.0/legalcode }}$

Vol. 9, No. 3, 2019, Pg. 208 - 218

http://hrmars.com/index.php/pages/detail/IJARBSS

JOURNAL HOMEPAGE

Full Terms \& Conditions of access and use can be found at http://hrmars.com/index.php/pages/detail/publication-ethics 


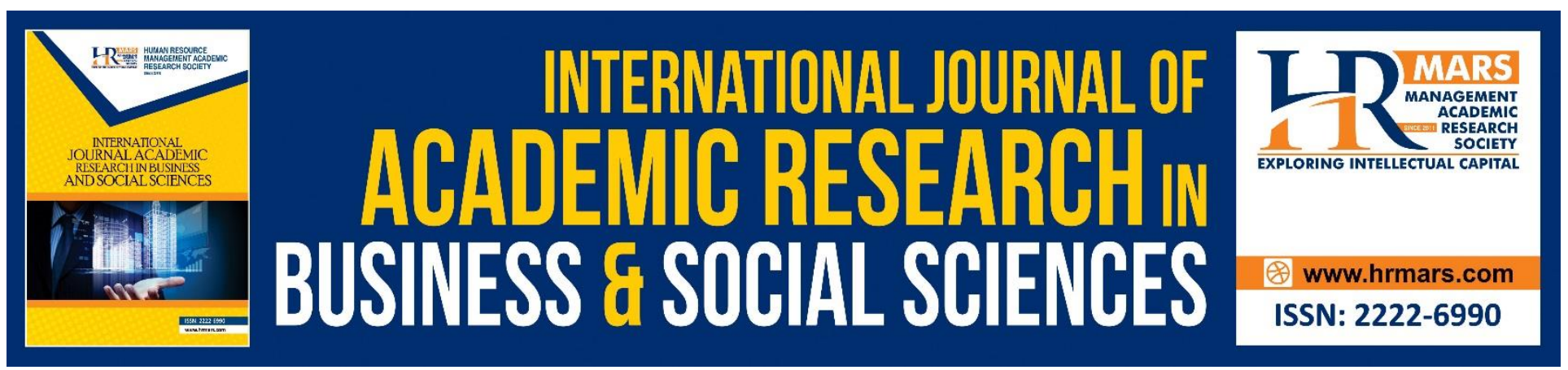

\title{
Interactions among Factors Affecting Micro Entrepreneur Performance in Sarawak, Malaysia
}

\author{
Habsah Mohamad Sabli \& Hamrila Abdul Latiff \\ Faculty of Economics and Business, Universiti Malaysia Sarawak, 94300 Kota Samarahan, Sarawak \\ Email: achenfardillah81@gmail.com, alhamrila@unimas.my
}

\begin{abstract}
Micro enterprise plays important role in achieving Malaysia's Vision 2020. Micro enterprises constitute about 76.5\% of all businesses in Malaysia and employ over 1.2 million employees. In this regard, out of the total 907,065 Malaysian SMEs, 693,670 (78.7\%) business foundations have been identified as micro enterprises (MEs) (Department of Statistics Malaysia, 2016). Hence, this paper analyses the factors affect the micro-entrepreneur's firm performance in Sarawak Malaysia. The research is based on 373 sample respondents from all over Sarawak with non-probability sampling and structured questionnaire had been used to collect response from the respondents. In terms of gender, female $(67.8 \%)$ respondents clearly outnumbered the male $(32.2 \%)$ respondents. AIM only offered loans to female micro entrepreneur while TEKUN and SEDC offered loans to both genders. The highest group of the micro entrepreneurs sampled in the present study, namely, more than onethird (39.8\%), fell into the age group of 26 to 36. The lowest age group was 59 to 69 (5\%). The respondents in this research were mostly micro entrepreneurs with more than two-thirds were educated up to secondary level MCE/SPM/SPMV (38\%) and lower secondary level LCE/SRP/PMR (27\%). Not even a quarter of the respondents were educated up to post-secondary and tertiary level education. Nevertheless, there were also a small number of them who had postgraduate qualifications, namely, Master's degree (0.5\%) and Ph.D. (0.3\%). The survey findings further revealed that the two identified factors (age and financial management knowledge) are significantly associated with micro entrepreneur compare to education level. The outcomes of this research can benefit the decision makers such as governments, microfinance institutions and other related institutions to support micro entrepreneur not only for poverty provision but also successful in firm performance. Keywords: Micro entrepreneur, age, education level, financial management knowledge and Malaysia
\end{abstract}

\section{INTRODUCTION}

Microfinance institutions (MFIs) have been the provider to micro entrepreneur which provides financial services (credit and saving) to the poor in order to release financial constraints and help alleviate poverty. Each MFI tries to maximize its repayment performance, whether it is profit oriented 
based. The Malaysia government supports the micro-entrepreneur by giving not only financial and credit assistance, but also technical and training assistance, extension and advisory services, marketing and market research, and infrastructure support (Skuras et al., 2003). Over RM9 billion in financial assistance was provided to more than 414,000 Bumiputera businesses. Programs such Amanah Ikhtiar Malaysia (AIM), TEKUN National, Malaysian Technology Development Corporation (MTDC), Malaysia Venture Capital Management Berhad, Malaysia Debt Ventures Berhad, and Multimedia Development Corporation (MDeC) is among providers of financial assistance to Bumiputera SMEs for their development and growth processes. Micro enterprises funded by the organization above are titled as microfinance and micro entrepreneur by the owner. Micro entrepreneurs in many nations have faced difficulties in obtaining funding, challenges in abusing innovation, deterioration in the quality of basic leadership abilities, low profitability and administrative weights in their business condition. Money-related proficiency among small-scale business visionaries assumes a crucial part and has a considerable effect on the performance of business insistently (Patrick, 2015). Furthermore, to start a new business, micro entrepreneurs need internal and external capital to fund the business. Having only capital resource from micro finance institutions is not sufficient enough without knowledge on financial management (Hashim \& Wafa, 2002). Moreover, an ability for a micro-entrepreneur to financially manage is key, in order to face new business challenges as well as for the survival of the business in the future (Salikin, Wahab, \& Muhammad, 2014). Hence, financial management knowledge is important and the key components of financial literacy. Through financial management knowledge, entrepreneurs can manage resources, products, personal finance, accounting, financial management systems, financial products and service options, financial risk, capital investment and legal and tax issues. If one has the advantage of having knowledge of financial management, micro entrepreneurs can make capital use planning from the start and identify investment opportunities (USAID, 2009). In Malaysia, the failure rate amongst SME relatively high 60 percent within five years operation (Wei, 2012). Therefore, this study aims to investigate the relationship between ages and financial management on micro entrepreneur performance in Sarawak, Malaysia.

The remainder of the chapter is systematized as follows: following present a literature review of past studies on the relationships between ages, education level and financial management knowledge with micro entrepreneur firm performance. Subsequent section of methodology employs and follow by findings. Lastly by conclusion and recommendations of this study.

\section{LITERATURE REVIEW}

Micro entrepreneur comes from different age, education background, marital status, and races which lead to their performance. The results from showed that age and education level are positively correlated with financial management and firm performance (Taft, Hosein, \& Mehrizi, 2013). Varied from research findings, which ages significantly negatively related to micro entrepreneur firm performance (Parotta \& Johnson, 1998; Titus et al., 1989; Mugenda et al., 1990; Davis \& Weber, 1990).

Education level among micro entrepreneur imperative elements to determine the successful of the business, findings from Ramachandran and Shah, (1999), level of education among indigenously owned Africans micro entrepreneur significantly positively contribute to the successful 
of their firms. Hence, the higher level of education, enable them to manage a business wisely and get the access to credit from formal financial institutions. However, findings from Samarakoon \& Parinduri, (2015) there is no evidence that education level improves women's decision-making authority, asset ownership or community participation.

According to Wanjohi (2011) lack of financial management education, training and capital, lead to difficulties in managing business funds secured for their business activities such as procuring raw materials and products, and investing in plant and equipment which can lead to unsuccessful firm performance, Morris (2001) points out that micro entrepreneurs need training in financial literacy to improve their knowledge in personal financial management. A study conducted by Drexler, Fischer and Schoar (2011) has indicated that micro entrepreneurs who have been provided with financial education that is oriented towards simple financial management knowledge have shown improvement in the financial behaviour which has resulted in statistical significance and economic improvement. The result has confirmed that financial management courses can have an impact on the performance of the firm. Further evidence has been found in the study conducted by Chimucheka and Rugani (2011) showed, micro entrepreneur in Buffalo City Municipality, South Africa have difficulty in gaining finance from formal financial institutions due to lack of financial knowledge in managing their business and have an impact on survival and growth. Another technique to enhance financial management knowledge is by storytelling. Storytelling creates an inner tension, a sense of anticipation or curiosity. This study has shown that the introduction of storytelling links student concentration and financial theory and has led to an enhancement in student performance. By incorporating a storytelling presentation, results of student performance reveal that a significant proportion of students have an increased recollection of the material covered. It was also found that this positive outcome was not related to the type of a class, but rather the increased interest in the lecture. These results support arguments that students that have a greater interest in the presentation have a perceived benefit between studying financial management and its practical applications (Bryant \& Harris, 2018).

Measuring micro entrepreneur firm performance has raised a debate from time to time, about which measurement should be used. Common measures of microfinance performance include both financial and non-financial indicators (organizational performance). The main content of arguments by researchers is that the researcher should implement and vindicate at least two different shape of solid performance, and that these were to be both financial and nonfinancial measures (Dimitratos et al. 2004). Murphy et al., (1996) suggested that, microfinance performance must be measure in a manifold dimension, which leads to better results, mutually considering financial and non-financial methods. Non-financial indicators such as self-management also contribute to the firm performance. Self-management is important since the micro entrepreneurs can manage their daily activity by themselves (i.e., time management) and avoid the unnecessary. The aforementioned factors lead to one becoming a successful entrepreneur which is central to successful firm performance (Lucky, 2011). Campbell (2007) has emphasized that non-financial indicators apparently contribute to "the financial indicators in determining the firm's overall performance and success" (p. 297). In addition, other measures of organization performance based on profitability, saving, sales, growth, employment and customer satisfaction (Cho et al., 2008) can also be considered. 


\section{METHODOLOGY}

The study is mainly a primary data-based descriptive analytical research. The sample of the research are the micro entrepreneur in Sarawak, Malaysia. The questionnaire adapted from OECD (2013) toolkits for measuring financial management and micro entrepreneur firm performance consists of non-financial measures which organizational performance (Cho et al. 2008). The first author personally distributed the questionnaires to 400 respondents in all over Sarawak and only 373 which $(95.3 \%)$ response rate questionnaire usable. This study utilized few common statistical tools to analyses the data. SPSS Version 23 was used for this purpose. The reliability tests on the identified variables for this study were found to be acceptable and reliable as the Cronbach's Alpha values for all the variables are above 0.60 . The following are the outcomes from the reliability tests: Financial Management knowledge (10 items; Cronbach's Alpha= 0.905); and micro entrepreneur non-financial performance ( 7 items; Cronbach's Alpha= 0.923).

\section{FINDING}

Data collection which started on October 2018 and finished in February 2019 took over a period of six months to be completed. A total of 14 types of demographic data was obtained using the frequency test. The demographic data of the profile of respondents comprised information about gender, age, marital status, religion, race, highest education, financial institutions, loan scheme, the total amount of financing (RM), the frequency of business financing sought or applied by the respondents and the number of year's business operation.

In terms of gender, female (67.8\%) respondents clearly outnumbered the male (32.2\%) respondents. AIM only offered loans to female micro entrepreneur while TEKUN and SEDC offered loans to both genders. The highest group of the micro entrepreneurs sampled in the present study, namely, more than one-third (39.8\%), fell into the age group of 26 to 36 . The lowest age group was 59 to 69 (5\%). Overall, more than three quarters of the micro entrepreneurs were married (79.3\%). Those who were unmarried were single (18.3\%) and divorced or widowed $(2.5 \%)$. Notably, the majority of respondents were Muslims (68.3\%) which comprised more than half of the sample. This was followed by Christians (23\%) who formed nearly a quarter of the respondents. Hindus (5.5\%) and Buddhists (2.3\%) formed less than one-tenth of the sample. A small number of the respondents did not belong to any of these religious groups (1\%). In terms of ethnicity, the top four groups of respondents were the indigenous groups of Sarawak natives called Melanau (30.5\%), followed by the Malays (26.5\%), the Ibans $(20.8 \%)$ and the Bidayuhs (10.0\%). The other ethnic groups such as the Indians and the Chinese were the small minorities with others as the lowest (1\%). The respondents in this research were mostly small micro entrepreneurs with more than two-thirds were educated up to secondary level MCE/SPM/SPMV (38\%) and lower secondary level LCE/SRP/PMR (27\%). Not even a quarter of the respondents were educated up to post-secondary and tertiary level education. Nevertheless, there were also a small number of them who had postgraduate qualifications, namely, Master's degree (0.5\%) and Ph.D. (0.3\%). Thus, the questionnaire was bilingual (i.e., Malay and English) and respondents should not have had problems in answering the questions.

Results showed that TEKUN was the highest financing organization (46\%) as nearly half of the total number of respondents received funding from it. This was followed by AIM (32\%) and lastly SEDC 
INTERNATIONAL JOURNAL OF ACADEMIC RESEARCH IN BUSINESS AND SOCIAL SCIENCES Vol. 9, No. 3, March, 2019, E-ISSN: 222 2-6990 @ 2019 HRMARS

(21.3\%). Business profile of the respondents indicated that the total amount financing below RM10, 000 was received by nearly three quarters of the respondents $(73.8 \%)$. The general trend showed that the total amount of financing received was inversely related with the number of respondents. In other words, as the amount increased, the number of respondents who received the financing decreased. However, this trend showed a slight change in the increase from $0.8 \%$ (RM31, 000-40, 000) to 3.3\% (RM41, 000-50,000). In terms of the frequency of business financing sought or applied by the respondents, more than one-third (32.8\%) of the respondents had applied twice. This was followed by three-time applicants (23.8\%) and one-time or first-time applicants (22.8\%). Only a small number of respondents (1\%) had frequently applied for funding up to four times. The analysis of the demographic data also indicated that nearly three quarters of the micro entrepreneurs (71.3\%) had been in operating their respective businesses for not more than 5 years. The percentage dropped drastically by $53.8 \%$ for micro entrepreneurs who had been in operation between 5 and 15 years (17.8\%). The downward trend then gradually continued with every increase in the number of years of operation with the lowest percentage $(0.5 \%)$ of micro entrepreneurs sampled in the present study having been in operation for 20 years or more. In addition, the most common type of business was retailing (27.5\%) which made up slightly more than one quarter, followed by manufacturing (20.3\%), agriculture (14.3\%) and services (11.5\%). Animal husbandry, fisheries and other types of business were the most uncommon of all with others being the lowest (1.8\%).

Table 1: Profiles of the Respondents

\begin{tabular}{|c|c|c|}
\hline Demographic Profile & Number of Respondent (N373) & Percentages (\%) \\
\hline \multicolumn{3}{|l|}{ Gender } \\
\hline \begin{tabular}{l|l} 
Male \\
\end{tabular} & 124 & 33.2 \\
\hline Female & 249 & 66.8 \\
\hline \multicolumn{3}{|l|}{ Age } \\
\hline \begin{tabular}{l|l|}
$15-25$ \\
\end{tabular} & 31 & 8.3 \\
\hline $26-36$ & 149 & 39.9 \\
\hline $37-47$ & 111 & 29.8 \\
\hline $48-58$ & 62 & 16.6 \\
\hline $59-69$ & 20 & 5.4 \\
\hline \multicolumn{3}{|l|}{ Married Status } \\
\hline \begin{tabular}{l|l} 
Single \\
\end{tabular} & 56 & 15 \\
\hline Married & 307 & 82.3 \\
\hline Others & 10 & 2.7 \\
\hline \multicolumn{3}{|l|}{ Religion } \\
\hline Muslim & 258 & 69.2 \\
\hline Christian & 84 & 22.5 \\
\hline Hindu & 22 & 5.9 \\
\hline Buddhist & 5 & 1.3 \\
\hline
\end{tabular}


INTERNATIONAL JOURNAL OF ACADEMIC RESEARCH IN BUSINESS AND SOCIAL SCIENCES Vol. 9, No. 3, March, 2019, E-ISSN: 222 2-6990 @ 2019 HRMARS

\begin{tabular}{|c|c|c|}
\hline Others & 4 & 1.1 \\
\hline \multicolumn{3}{|l|}{ Race } \\
\hline Malay & 97 & 26 \\
\hline Chinese & 14 & 3.8 \\
\hline Melanau & 121 & 32.4 \\
\hline Iban & 82 & 22 \\
\hline Bidayuh & 33 & 8.8 \\
\hline \begin{tabular}{|l|} 
Indian \\
\end{tabular} & 26 & 7.0 \\
\hline \multicolumn{3}{|l|}{ Education Level } \\
\hline \begin{tabular}{l|l} 
Ph.D. \\
\end{tabular} & 1 & .3 \\
\hline Master & 1 & .3 \\
\hline Degree & 9 & 2.4 \\
\hline Diploma/STPM & 59 & 15.8 \\
\hline MCE/SPM/SPMV & 145 & 38.9 \\
\hline LCE/SRP/PMR & 108 & 29.0 \\
\hline Others & 50 & 13.4 \\
\hline \multicolumn{3}{|l|}{ Financing Organization } \\
\hline AIM & 116 & 31.1 \\
\hline Tekun & 169 & 45.3 \\
\hline SEDC & 85 & 22.8 \\
\hline Others & 3 & .8 \\
\hline \multicolumn{3}{|l|}{ Total Amount Financing } \\
\hline \begin{tabular}{l|l} 
Rm1000-Rm10,000
\end{tabular} & 279 & 74.8 \\
\hline $\operatorname{Rm} 11,000=\operatorname{Rm} 20,000$ & 67 & 18.0 \\
\hline Rm21,000-Rm30,000 & 14 & 3.8 \\
\hline Rm31,000-Rm40,000 & 3 & 8 \\
\hline Rm41000-Rm50,000 & 10 & 2.7 \\
\hline \multicolumn{3}{|l|}{ Number of Times } \\
\hline \begin{tabular}{l|l}
$1 x$ \\
\end{tabular} & 89 & 23.9 \\
\hline $2 x$ & 127 & 34 \\
\hline $3 x$ & 95 & 25.5 \\
\hline $4 x$ & 58 & 15.5 \\
\hline$>4 x$ & 4 & 1.1 \\
\hline \multicolumn{3}{|l|}{ Years Operate1. } \\
\hline $1-5$ & 258 & 69.2 \\
\hline $6-10$ & 71 & 19.0 \\
\hline $11-15$ & 39 & 10.5 \\
\hline $16-20$ & 3 & .8 \\
\hline$>20$ & 2 & .5 \\
\hline
\end{tabular}


Furthermore, the method of multiple linear regression technique with a significance level of 0.05 is used to identify the most dominant factor affect micro entrepreneur performance. The independent variables were the age, education level and financial management knowledge. The dependent variable indicated micro entrepreneur performance. According to the Table 2, all of the independent variables affect micro entrepreneur performance. The highest coefficient for financial management knowledge is $(0.428)$; followed by age $(0.155)$ and lastly education level $(-0.127)$. This explains financial management knowledge the most influential towards micro entrepreneur performance. The general form of the regression equation to predict micro entrepreneur performance from age, education level and financial management knowledge, which obtained from the coefficient is:

Micro Entrepreneur Firm Performance $=2.993+0.115 A+0.127 E L+0.428 F M$

Table 2: Multiple Linear Regression equation for the Micro Entrepreneur Performance

\begin{tabular}{|l|l|l|l|l|l|}
\hline \multirow{2}{*}{ Model } & \multicolumn{2}{l|l|l|}{$\begin{array}{l}\text { Unstandardized } \\
\text { Coefficients }\end{array}$} & $\begin{array}{l}\text { Standardized } \\
\text { Coefficients }\end{array}$ & \multirow{2}{*}{ t } & sig \\
\cline { 2 - 6 } & $\mathrm{B}$ & Std Error & Beta & & .000 \\
\hline (Constant) & 2.993 & .305 & & 9.820 & .00 \\
\hline Age & .155 & .049 & .159 & 3.179 & .002 \\
\hline Education Level & -.127 & .050 & -.131 & -2.545 & .011 \\
\hline $\begin{array}{l}\text { Financial Management } \\
\text { Knowledge }\end{array}$ & .428 & .038 & .501 & 11.136 & .000 \\
\hline
\end{tabular}

a. Dependent variables: Micro Entrepreneur Performance

As illustrated in Table 3, the value of $\mathrm{R}$ is considered in measuring the quality of prediction of the dependent variable. In this study, the value of $R$ which represents the multiple coefficients is 0.549 , a good level of prediction. The value of $\mathrm{R} 2$ represents the coefficient of determination, which verifies the proportion of variance in the dependent variable that can be explained by the independent variables. It can be seen that value of 0.302 means about only $30 \%$ of the variable refers to the micro-entrepreneur performance in Sarawak, Malaysia. The regression equation appears to be very helpful for making predictions since then the value of R2 is close to 1.

Table 3: Interpretation and computation of the coefficient of multiple determinations, $\left(R^{2}\right)$ Model Summary

\begin{tabular}{|l|l|l|l|l|}
\hline Model & R & R Square & $\begin{array}{l}\text { Adjusted } \mathbf{R} \\
\text { Square }\end{array}$ & $\begin{array}{l}\text { Std Error of the } \\
\text { estimate }\end{array}$ \\
\hline 1 & $.549^{a}$ & .302 & .296 & .83348 \\
\hline
\end{tabular}

Using Pearson Correlation Coefficient test, this study found that two of the identified factors have significant relationships with micro entrepreneur performance. In this case, Table 4 shows that: age with micro entrepreneur performance has correlation coefficient of 0.516 and its $p$ value is smaller than 0.05; Financial management knowledge has correlation coefficient of 0.098 and its $p$ 
INTERNATIONAL JOURNAL OF ACADEMIC RESEARCH IN BUSINESS AND SOCIAL SCIENCES

Vol. 9, No. 3, March, 2019, E-ISSN: 222 2-6990 @ 2019 HRMARS

value is smaller than 0.05 .and lastly Education level has no significantly correlate of 0.009 and its $p$ value is higher than 0.05 . Overall, the outcomes from the research clearly revealed education level not contribute to the micro entrepreneur performance.

Table 4: Pearson Correlations for Identified Factors and Micro Entrepreneur Performance

\begin{tabular}{|l|l|l|}
\hline Variables & Significant value (p) & Pearson Correlation (rs) \\
\hline Age & 0.000 & 0.516 \\
\hline Education Level & 0.860 & 0.009 \\
\hline Financial management knowledge & 0.050 & 0.098 \\
\hline
\end{tabular}

Note: Significant value with $p \leq 0.05$

\section{CONCLUSION AND RECOMENDATIONS}

The main objective of this study is to identify the factors and relationships between age, education level and financial management knowledge with micro entrepreneur performance. The first objective shows age is significantly associated with micro entrepreneur performance. This objective support by the results from Taft, Hosein, \& Mehrizi, (2013) showed that age and education level are positively correlated with micro entrepreneur firm performance. Secondly, the objective which has revealed that education level does not affect micro entrepreneur performance which shows that the business still can function without higher education among the micro-entrepreneur. This consistent with findings from Dickson, Solomon \& Weaver (2008) shows the insignificant relationship between education and entrepreneurial performance or success. Lastly, financial management significantly associates with micro entrepreneur performance which aligns with the study from Drexler et al. (2011), shows micro entrepreneurs given financial education oriented towards simple financial management knowledge, showed improvement in the financial behavior, statistically significance and economically improvement. The result confirmed how financial management courses can impact on firm performance. Furthermore, microfinance institutions should provide courses/seminars and train on financial management to micro entrepreneurs. The course should be done comprehensively among entrepreneurs so that knowledge of financial management can be practiced in the business. Periodic monitoring is also important in order for financial management to be applied extensively to ensure their successful business development.

\section{References}

Beck, T., \& Demirguc-Kunt, A. (2006). Small and Medium-Size Enterprises: Access to Finance as a Growth Constraint. Journal of Banking and Finance, 30(11), 2931-2943. doi.Org/10.1016/J.Jbankfin.2006.05.009

Bryant, L., \& Harris, R. (n.d.). Using storytelling to increase interest and recollection in finance concepts, 1-11.

Chimucheka, T., \& Rungani, E. C. (2011). The impact of inaccessibility to bank finance and lack of financial management knowledge to small, medium and micro enterprises in Buffalo City Municipality, South Africa. African Journal of Business Management, 5(14), 5509-5517. https://doi.org/10.5897/AJBM11.806 
INTERNATIONAL JOURNAL OF ACADEMIC RESEARCH IN BUSINESS AND SOCIAL SCIENCES

Vol. 9, No. 3, March, 2019, E-ISSN: 222 2-6990 @ 2019 HRMARS

Dickson, Pat H, Weaver, K. Mark and Solomon, George T. Entrepreneurial selection and success: does education matter? Journal of Small Business and Enterprise Development, 15(2), 239-258.

Dimitratos, P., Lioukas, S., \& Carter, S. (2004). The relationship between entrepreneurship and international performance: the importance of domestic environment. Journal of International Business Review, 13(10), 19-41.

Drexler, A., Fischer, G. \& Schoar, A. (2010). Keeping it simple: financial literacy and rules of thumb. Centre for economic and management studies, 1(2), Economic Policy Research Discussion Paper September.

Man, T. W.Y., Lau. T. \& Snape, E. (2008). Entrepreneurial competencies and the performance of small and medium enterprises: An investigation through a Framework of Competitiveness: Journal of Small Business and Entrepreneurship 21, (20), 21-29.

Mandell, L. (2004), Financial Literacy: Are We Improving? JumpStart Coalition for Personal Financial Literacy, Washington, DC

Moris, Schindehutte. \& Minet, Michael. (2000). Adaptation as a core entrepreneurial competency: components, antecedents, and outcomes. American Marketing Association. Conference Proceedings; 2000.

Muhammad, M. A. (2009). The combine effect of market orientation and owner/manager's innovation and business performance of small and medium sized manufacturing firms in Pakistan. Sintok, Kedah, Malaysia: PhD Thesis, UUM.

Murphy, G.B., J.W. Trailer \& R.C. Hill. (1996). Measuring performance in entrepreneurship. Journal of Business Research, 36(1), 15-23.

Nurulhasanah Abdul Rahman, Zulnaidi Yaacob, \& Rafisah Mat Radzi. (2014). DETERMINANTS OF SUCCESSFUL FINANCIAL MANAGEMENT AMONG MICRO ENTREPRENEUR IN MALAYSIA Nurulhasanah Abdul Rahman Zulnaidi Yaacob Rafisah Mat Radzi Contribution / Originality. Journal of Asian Scientific Research, 4(11), 631-639.

OECD. (2012). Measuring entrepreneurial finance: A European survey of SMEs. In: Entrepreneurship at a Glance. OECD Publishing. Available at: doi.org/10.1787/entrepreneur_aag-2012-5-en

OECD. (2013). Alternative financing instruments for SMEs and entrepreneurs: The Case of Mezzanine Finance. Report no. CFE/SME (2012)9/FINAL, OECD, Paris.

Parrota, J. L., \& Johnson, P. J. (1998). The impact of financial attitude and knowledge on financial management and satisfaction Of Recently Married Individuals. Journal of Financial Counseling and Planning, 9(2), 59-75. https://doi.org/10.5897/AJBM10.1267

Ramachandran, V., \& Shah, M. K. (1999). Minority entrepreneurs and firm performance in subSaharan Africa. Journal of Development Studies, 36(2), 71-87. https://doi.org/10.1080/00220389908422621

Sabana, Beatrice \& Gathungu, J. M. (2014). Entrepreneur Financial Literacy, Financial Access, Transaction Costs and Performance of Micro Enterprises in Nairobi City County, Kenya. International Journal of Research in Management, Economics and Commerce, 1(2), 25-30. https://doi.org/10.1163/1570756042729519

Salikin, N., Wahab, N. A., \& Muhammad, I. (2014). Strengths and Weaknesses among Malaysian SMEs: Financial Management Perspectives. Procedia - Social and Behavioral Sciences, 129, 334-340. https://doi.org/10.1016/j.sbspro.2014.03.685 
Samarakoon, S., \& Parinduri, R. A. (2015). Does Education Empower Women ? Evidence from Indonesia. World Development, 66, 428-442. https://doi.org/10.1016/j.worlddev.2014.09.002

Shamsudeen, K., Keat, O. Y., \& Hassan, H. (2015). Access to microfinance as potential mediator on the relationship between microfinance awareness and entrepreneurial self-efficacy on SME Performance in Nigeria: An empirical study. Conference on Business Management Research II (CBMR II 2015), (December), 52-65.

Skuras, D., Caldas, J.C., Meccheri, N., Psaltopoulos, P., and Viladomiu, L. (2003). Institutional support to strategic business orientations: an empirical analysis of rural business in four countries of southern Europe. European Business Review. 15(4), 235-244.

Taft, M. K., Hosein, Z. Z., \& Mehrizi, S. M. T. (2013). The Relation between Financial Literacy, Financial Wellbeing and Financial Concerns. International Journal of Business and Management, 8(11), 63-75. https://doi.org/10.5539/ijbm.v8n11p63

USAID. (2009). Development of strategy options for SME financial literacy, Final Report. Retrieved from http://pdf.usaid.gov/pdf_docs/PNADP093.pdf

USAID (2005): MSME Demand Mapping Survey, Nigeria.

Wanjohi, A (2011) Kenya Vision 2030 and youth agenda. Kenpro Papers Portal. Available http://www.kenpro.org/tag/sme-sector-in-kenya/ retrieved on 30th July 2015.

Wei, Y. C. (2012). Critical Success Factors for Small and Medium Enterprises: Perceptions of Entrepreneurs in Urban Malaysia. Journal of Business and Policy Research, 7(4), 204-215.

Worthington, A. C. 2004. The Distribution of Financial Literacy in Australia. Discussion Papers in Economics, Finance, and International Competitiveness. Queensland University of Technology, November. 